\title{
水質污濁防止法
}

\author{
河 原崎 海* \\ 株式会社エコプロ・リサーチ \\ （2015年 5 月 27 日受理）
}

\section{Water Pollution Control Act}

\author{
Kai KaWARAZAKI \\ Eco Pro Research Co., Ltd., 100 Shibukawa, Shimizuku, Shizuoka 424-0053, Japan
}

Keywords: water pollution control act, pesticide.

\section{はじめに}

われわれの生活環境の保全と公害の防止のために，環境関 係の法令か制定されている．環境関係法令の構成は環境基本 法で政策方針を定め，具体的な施策は，個別の環境法で定め られている（図1)。環境法は，人の健康被害の防止と生活 環境の保全を目的とした規制法である。この規制法には大気 污染防止法，水質污濁防止法，土壌污染対策法等さまざまな ものがあるが，今回は水質污濁防止法について，概要及び農 薬と関連か強い部分について解説する。

\section{1. 制定の背景及び目的}

戦後の高度経済成長に伴う公害問題の深刻化を受け, 1958年に「公共用水域の水質の保全に関する法律（水質保 全法）」と「工場排水等の規制に関する法律（工場排水規 制法）」が制定された（合わせて「水質二法」と呼ばれてい る)。しかし，水質二法は，指定された水域だけを規制対象 とすることや，いわゆる経済調和条項が盛り込まれていたこ となどから，公害を未然に防ぐ機能にはそしかった。そこ

\footnotetext{
* = 424-0053 静岡県静岡市清水区渋川100 番地

E-mail: kawarazaki@ecopro-res.co.jp

(c) 日本農薬学会
}

で，1970年のいわゆる公害国会において，水の污濁に対す る未然防止的な規制を図るため，水質二法を廃止して新たに 「水質污濁防止法」が制定された。またこの法律では水質の 污濁を規制することにより，国民の健康保護と生活環境保全 を行い，工場や事業所から排出される污水等により健康被害 が生じた場合の事業者責任について定めることで被害者の保 護を図ることとなっている，水質污濁防止法は，污濁物質の 主要な発生源である工場や事業場から公共用水域に排出され る水と地下に浸透する水を規制することとして扔り，水質二 法における指定水域に偏った規制から，全般的な規制に改め られている．また，有害物質や污染水を排出する施設は「特 定施設」とされ，特定施設を設置する工場や事業場を「特定 事業場」として，規制対象の中心に位置づけている。また有 害物質貯蔵指定施設を設置する事業場も規制対象となってい る. 特定施設については, 水質污濁防止法施行令で定めら れており, 平成26年3月末時点において, 水質污濁防止法 上の特定施設を持つ特定事業場数は 265,964 であり ${ }^{1)}$, 平成 25 年 3 月末時点と比較すると, 特定事業場数は約 1 千件減少 している．特定施設は 100 余りの施設カテゴリー分類される が，このうち届出数の多い上位 10 施設を表 1 に示した。施 設カテゴリーのうち「農薬製造業」は29事業場，「科学技術 に関する研究・試験・検査を行う事業場」は4,771事業場と なっている. 


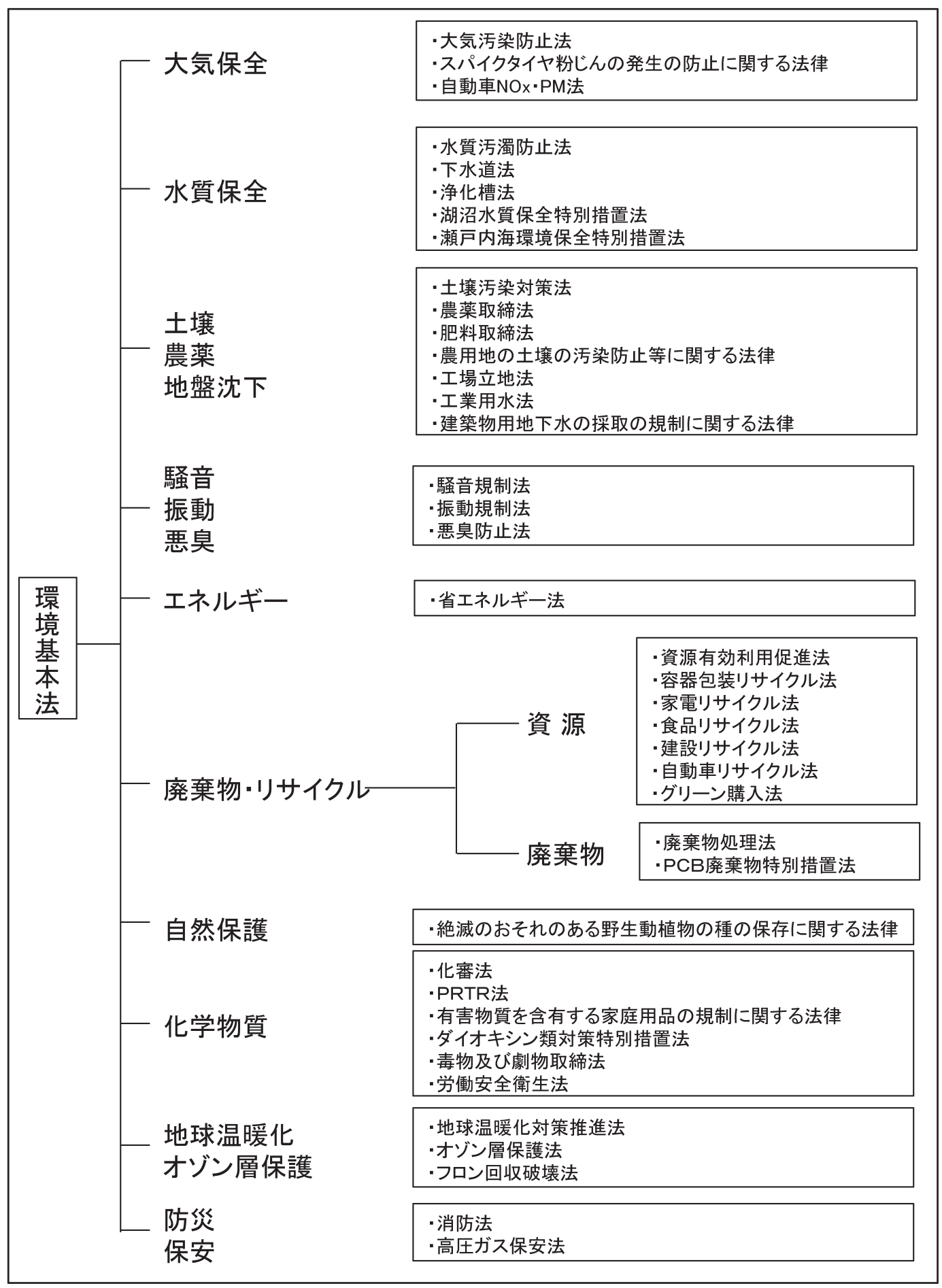

図 1. 環境関連法規の体系図.

\section{2. 内容及び解説}

特定施設から排出される污水または廃液を「污水等」と し，特定事業場から公共用水域に排出される水を「排出水」 と定義している. 排水基準は, 排出水の污染状態について, 環境省令で定めることとされているが，国の排水基準では人 の健康を保護し，または生活環境を保全することが十分でな
いと認められる区域があるときは，都道府県の条例で，国の 排水基準で定める許容限度よりきびしい排水基準を定めるこ とができるとされている．特定事業場からの排出水について は，その污染状態が特定事業場の排水口において排水基準に 適合しない排出水を排出してはならないとされており，排出 水の濃度が規制されている。一方濃度規制だけでは, 希釈す 
表 1. 特定事業場の上位 10 業種（平成 25 年度 $)^{1)}$

\begin{tabular}{|c|c|c|c|c|}
\hline 順位 & 業種・施設名 & 事業場数（構成比*） & $\begin{array}{c}\text { 一日当たりの平均排水量 } \\
50 \mathrm{~m}^{3} \text { 以上の事業場数 }\end{array}$ & $\begin{array}{c}\text { 一日当たりの平均排水量 } \\
50 \mathrm{~m}^{3} \text { 未満の事業場数 }\end{array}$ \\
\hline 1 & 旅館業 & $63,061(23 \%)$ & 4,139 & 58,922 \\
\hline 2 & 自動式車両洗浄施設 & $30,819(11 \%)$ & 101 & 30,718 \\
\hline 3 & 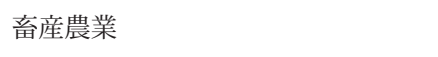 & $27,791(10 \%)$ & 391 & 27,400 \\
\hline 4 & 洗濯業 & $22,141 \quad(8 \%)$ & 495 & 21,646 \\
\hline 5 & 豆腐・煮豆製造業 & $11,789(4 \%)$ & 287 & 11,502 \\
\hline 6 & し尿処理施設 & $11,654(4 \%)$ & 9,868 & 1,786 \\
\hline 7 & $\begin{array}{l}\text { 乙尿浄化槽（201 人以上 } 500 \text { 人以下） } \\
\text { （指定地域特定施設） }\end{array}$ & $10,203 \quad(4 \%)$ & 2,262 & 7,941 \\
\hline 8 & 水産食料品製造業 & $8,487(3 \%)$ & 667 & 7,820 \\
\hline 9 & 酸・アルカリ表面処理施設 & $5,945(2 \%)$ & 1,340 & 4,605 \\
\hline 10 & 写真現像業 & $5,942(2 \%)$ & 16 & 5,926 \\
\hline & 総計 & $197,832(73 \%)$ & 19,566 & 178,266 \\
\hline
\end{tabular}

*構成比は, 全特定事業場に占める割合を表す.

ることにより多量の污濁物質が排出可能になることや, 瀬戸 内海, 東京湾などの閉鎖性水域の污濁が懸念されたことなど から, 污濁物質の総量についても1978年の改正により規制 が設けられている(いわゆる総量規制).

水質污濁防止法では, 有害物質による污染状態 (健康項 目）とその他の污染状態（生活環境項目）が規制の対象と なっており, 健康項目としては, カドミウム, シアン化合 物, 鉛, 六価クロムなど 28 項目が定められ, 許容限度が設 定されている (表2). 生活環境項目については, 水素イオ ン濃度や浮遊物質量, 大腸菌群数など 15 項目について許容 限度が示されている（表 3)。健康項目についての規制はす べての特定事業場に適用されるのに対し，生活環境項目につ いての規制は, 一日あたりの平均的な排出水量が $50 \mathrm{~m}^{3}$ 未満 の特定事業場には適用されないことになっている.

規制物質の中で農薬に的を絞ってみると，一律排水基準で は有機リン化合物（パラチオン，メチルパラチオン，メチル ジメトン及び $\mathrm{EPN}$ の合算值), チウラム, シマジン, チオべ ンカルブ，1,3-ジクロロプロペンの計 5 項目に基準值が設定 されている，他には直接水濁法で規制されてはいないが，農 薬取締法第 3 条第 1 項第 7 号に基づく水質污濁に係る農薬登 録保留基準が定められているほか, 地方公共団体が水質保全 の面から農薬を使用するゴルフ場を指導する際の参考となる よう, ゴルフ場で使用される農薬による水質污濁の防止に係 る暫定指導指針を定めている.

今回は一律排水基準, 水質污濁に係る登録保留基準及び

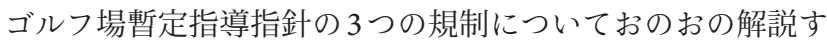
る.

\section{1. 一律排水基準}

水濁法では環境大臣の定める全国一律の一律排水基準と水 域ごとの上乗せ基準の二段階の設定がある.ある水域におけ る水質が，一律排水基準による規制だけでは不十分である場 合には, 都道府県は条例でこれらの基準に代えて適用するよ り厳しい基準を定めることができる。これを「上乗せ規制」 といい，この基準値を「上乗せ基準」と呼ぶ。. 国が定めた一 律排水基準值より厳しい基準值を定めることが狭義の上乗せ 規制であるが，広義には国が定めた規制対象施設の範囲をよ り小規模なものにまでひろげる場合（「裾下げ」という）や， 国が定めた規制項目以外の規制項目を追加する場合（「横出 し」という）も含めて使われる。 なお，水質污濁防止法第 3 条に基づく上乗せ排水基準は昭和 50 年度以降すべての都道 府県で定められている。これらの基準に対して特定事業場か ら公共用水域へ排出される水が基準を超過した場合には, 直 罰（違法行為があった場合に, 行政指導や行政命令を出して 自主的な改善を促すといった過程を経ることなく, 即時に懲 役や罰金などの罰則を適用することを定めた規定）が科せら れる.

\section{2. 水質污濁に係る農薬登録保留基準}

農薬は, 農薬取締法3 条に基づき, 農林水産大臣の登録を 受けたものでなければ製造・販売・使用等ができないが，農 薬の登録を認めるか否かの判断基準のうち，（1）作物残留, （2）土鎄残留，（3）水産動植物の被害防止，（4）水質污濁 に関する基準（農薬登録保留基準）を環境大臣か設定してい る. 平成26年度においては, 水産動植物の被害防止に係る 登録保留基準について 53 農薬に基準值が設定され，24農薬 を基準值設定不要とした。また，水質污濁に係る農薬登録 
表 2. 一律排水基準 (健康項目) ${ }^{2)}$

\begin{tabular}{|c|c|}
\hline 有害物質の種類 & 許容限度 \\
\hline カドミウム及びその化合物 & $0.03 \mathrm{mg} \mathrm{Cd} / \mathrm{L}$ \\
\hline 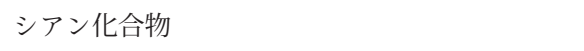 & $1 \mathrm{mg} \mathrm{CN} / \mathrm{L}$ \\
\hline $\begin{array}{l}\text { 有機燐化合物（パラチオン, メチルパラチオン, } \\
\text { メチルジメトン及びEPNに限る.） }\end{array}$ & $1 \mathrm{mg} / \mathrm{L}$ \\
\hline 鉛及びその化合物 & $0.1 \mathrm{mg} \mathrm{Pb} / \mathrm{L}$ \\
\hline 六価クロム化合物 & $0.5 \mathrm{mg} \mathrm{Cr}(\mathrm{VI}) / \mathrm{L}$ \\
\hline 吪素及びその化合物 & $0.1 \mathrm{mg} \mathrm{As} / \mathrm{L}$ \\
\hline 水銀及びアルキル水銀その他の水銀化合物 & $0.005 \mathrm{mg} \mathrm{Hg} / \mathrm{L}$ \\
\hline アルキル水銀化合物 & 検出されないこと. \\
\hline ポリ塩化ビフェニル & $0.003 \mathrm{mg} / \mathrm{L}$ \\
\hline トリクロロエチレン & $0.3 \mathrm{mg} / \mathrm{L}$ \\
\hline テトラクロロエチレン & $0.1 \mathrm{mg} / \mathrm{L}$ \\
\hline ジクロロメタン & $0.2 \mathrm{mg} / \mathrm{L}$ \\
\hline 四塩化炭素 & $0.02 \mathrm{mg} / \mathrm{L}$ \\
\hline 1,2-ジクロロエタン & $0.04 \mathrm{mg} / \mathrm{L}$ \\
\hline 1,1-ジクロロエチレン & $1 \mathrm{mg} / \mathrm{L}$ \\
\hline シス-1,2-ジクロロエチレン & $0.4 \mathrm{mg} / \mathrm{L}$ \\
\hline 1,1,1-トリクロロエタン & $3 \mathrm{mg} / \mathrm{L}$ \\
\hline 1,1,2-トリクロロエタン & $0.06 \mathrm{mg} / \mathrm{L}$ \\
\hline 1,3-ジクロロプロペン & $0.02 \mathrm{mg} / \mathrm{L}$ \\
\hline チウラム & $0.06 \mathrm{mg} / \mathrm{L}$ \\
\hline 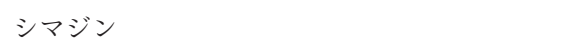 & $0.03 \mathrm{mg} / \mathrm{L}$ \\
\hline チオベンカルブ & $0.2 \mathrm{mg} / \mathrm{L}$ \\
\hline ベンゼン & $0.1 \mathrm{mg} / \mathrm{L}$ \\
\hline セレン及びその化合物 & $0.1 \mathrm{mg} \mathrm{Se} / \mathrm{L}$ \\
\hline \multicolumn{2}{|l|}{ ほう素及びその化合物 } \\
\hline 海域以外の公共用水域に排出されるもの： & $10 \mathrm{mg} \mathrm{B} / \mathrm{L}$ \\
\hline 海域に排出されるもの： & $230 \mathrm{mg} \mathrm{B} / \mathrm{L}$ \\
\hline \multicolumn{2}{|l|}{ ふっ素及びその化合物 } \\
\hline 海域以外の公共用水域に排出されるもの： & $8 \mathrm{mg} \mathrm{F} / \mathrm{L}$ \\
\hline 海域に排出されるもの： & $15 \mathrm{mg} \mathrm{F} / \mathrm{L}$ \\
\hline \multicolumn{2}{|c|}{ アンモニア, アンモニウム化合物, 亜硝酸化合物及び硝酸化合物 } \\
\hline $\begin{array}{l}\text { アンモニア性窒素に } 0.4 \text { を乗じたもの，亜硝 } \\
\text { 酸性窒素及び硝酸性窒素の合計量： }\end{array}$ & $100 \mathrm{mg} / \mathrm{L}$ \\
\hline 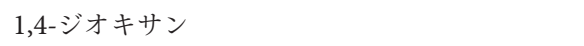 & $0.5 \mathrm{mg} / \mathrm{L}$ \\
\hline
\end{tabular}

保留基準については，23農薬に基準值を設定し，24農薬を 基準值設定不要とした ${ }^{3)}$ 。この中で今回のテーマと関連する （4）の水質污濁に関する部分について概説する.

農薬の登録時期によって規制が異なるが，農薬登録の更新 は 3 年ごとのため, 現在適用されるのは,「平成 18 年 8 月 3 日 以降に登録」の場合に限られる。この規制の中では，使用し た農薬が公共水域に流出または飛散することによって, 次の （イ）（二）のいずれかに該当する場合は，登録が保留とな る.
表 3. 一律排水基準 (生活環境項目) ${ }^{2)}$

\begin{tabular}{|c|c|}
\hline 項目 & 許容限度 \\
\hline \multicolumn{2}{|l|}{ 水素イオン濃度（水素指数）(pH） } \\
\hline $\begin{array}{l}\text { 海域以外の公共用水域に排出される } \\
\text { もの： }\end{array}$ & 5.8 以上 8.6 以下 \\
\hline 海域に排出されるもの： & 5.0 以上 9.0 以下 \\
\hline 生物化学的酸素要求量（BOD） & $160 \mathrm{mg} / \mathrm{L}$ （日間平均 $120 \mathrm{mg} / \mathrm{L}$ ） \\
\hline 化学的酸素要求量（COD） & $160 \mathrm{mg} / \mathrm{L}$ （日間平均 $120 \mathrm{mg} / \mathrm{L}$ ) \\
\hline 浮遊物質量（SS） & $200 \mathrm{mg} / \mathrm{L}$ （日間平均 $150 \mathrm{mg} / \mathrm{L}$ ） \\
\hline $\begin{array}{l}\text { ノルマルヘキサン抽出物質含有量 } \\
\text { (鉱油類含有量) }\end{array}$ & $5 \mathrm{mg} / \mathrm{L}$ \\
\hline $\begin{array}{l}\text { ノルマルヘキサン抽出物質含有量 } \\
\text { （動植物油脂類含有量） }\end{array}$ & $30 \mathrm{mg} / \mathrm{L}$ \\
\hline フェノール類含有量 & $5 \mathrm{mg} / \mathrm{L}$ \\
\hline 銅含有量 & $3 \mathrm{mg} / \mathrm{L}$ \\
\hline 亜鉛含有量 & $2 \mathrm{mg} / \mathrm{L}$ \\
\hline 溶解性鉄含有量 & $10 \mathrm{mg} / \mathrm{L}$ \\
\hline 溶解性マンガン含有量 & $10 \mathrm{mg} / \mathrm{L}$ \\
\hline クロム含有量 & $2 \mathrm{mg} / \mathrm{L}$ \\
\hline 大腸菌群数 & 日間平均 3000 個 $/ \mathrm{cm}^{3}$ \\
\hline 窒素含有量 & $120 \mathrm{mg} / \mathrm{L}$ （日間平均 $60 \mathrm{mg} / \mathrm{L}$ ） \\
\hline 燐含有量 & 16 mg/L（日間平均 8 mg/L） \\
\hline
\end{tabular}

（イ）水質污濁に係る環境中予測濃度が環境大臣の定める基 準値に適合しない場合

（口）残留農薬基準（本基準）が定められている場合

（ハ）残留農薬基準（暫定基準）が定められている場合

（二）本基準・暫定基準が定められていない場合

平成 18 年以前と以降で評価方法が異なるが、改正の背景 や主な改正点は下記の通りである。

\section{〈背景〉}

環境省では水濁基準を適切に施行するため, 平成 17 年度 に「水質污濁に係る環境中予測濃度（水濁PEC）算定方法 検討調查事業」を実施し, 水濁PECの算定方法を取りまと めたところであるが, 許容一日摂取量（ADI）が設定されて いない非食用農作物のみに使用される農薬の安全性評価の方 法をはじめとして, 個別農薬ごとの安全性評価及び基準值を 設定する必要性があることから改正が行なわれた。

〈主な改正内容〉

(1)水田使用農薬のみならず，非水田使用農薬も含めて原則す べての農薬について基準值を設定する.

(2)基準值の設定にあたっては, 飲料水からの農薬暴露に加え て, 生物濃縮係数が 5,000 を超える農薬については魚介類 の摂取による曝露を考慮して基準值を設定する.

(3)暴露評価の指標として, 従来の水田水中における 150 日 間の平均濃度に代わり, 当該農薬を使用した場合の水濁 PEC を用いることとし，水濁PECの值が基準值を超えな 
いこと.

(4)平成 18 年 8 月 3 日より前にされた登録の申請に関しては, 従前の基準を適用して, 改正前の水濁基準に従い基準值が 設定される.

〈基準值設定の基本的考え方〉

基準值は，公共用水域の水質污濁による農薬暴露が $\mathrm{ADI}$ の $10 \%$ を超えることがないように公共用水域の水中におけ る農薬の濃度について，ADIを基礎として設定される。た だし，生物濃縮係数（BCF）が5,000を超える農薬について は，飲料水の摂取による暴露 $10 \%$ に魚介類の摂取による暴 露を $5 \%$ として加算し，15\%とする．食品安全委員会におい て安全性評価が行われる農薬に係る基準值設定新規登録申請 があった農薬，食品衛生法に基づくポジティブリスト制度に より暫定基準が設定された農薬等，食品安全委員会におい て安全性評価（食品健康影響評価）が行われる農薬の水濁基 準值設定にあたっては，食品安全委員会により設定された ADI を優先して用いる. ただし, 食品安全委員会による食 品健康影響評価が未実施の農薬にあっては, 厚生労働省また は環境省が設置した審議会等において設定されたADIを用 いて基準值を設定できる，なお，基準值設定後に当該農薬に 係る食品安全委員会による食品健康影響評価が実施された場 合には，必要に応じて基準值が見直される。

\section{3・ゴルフ場で使用される農薬による水質污濁の防止に 係る暫定指導指針}

ゴルフ場で使用される農薬による水質污濁を未然に防止す るため, 農薬の使用に当たっては, 農薬取締法（昭和 23 年 法律第 82 号）に基づき安全性評価がなされた登録農薬の適 正使用や使用量の削減等について実効性を持った指導が徹底 される必要がある。このためゴルフ場から排出される水に含 まれる農薬の実態把握を行い，その結果に基づき，地方公共 団体がゴルフ場に対して適切な改善措置を求められるように 定めた指針である。

（1）農薬使用状況等の的確な把握

行政が水質保全の面からゴルフ場を指導する際には，事前 に農薬の使用状況やゴルフ場内の集排水系統, 排水処理施設 の現状，接続する河川，利水施設等ゴルフ場周辺水域の状況 等に関する実態を的確に把握することが必要である。このた め, 農薬を使用する者が遵守す心゙き基準を定める省令（平成 15 年 3 月 7 日農林水産省・環境省令第 5 号）第 5 条に基づき 毎年提出される農薬使用計画書などから調査項目の設定が行 われる。

（2）農薬流出実態の調査

ゴルフ場周辺の水域に対する水質污濁を未然に防止する観 点から，（1）により把握した情報を踏まえ，ゴルフ場排出水 に含まれる農薬濃度を調査し，この結果に基づき指導が行わ れる.このため, 農薬の流出実態の調査は, 排出水がゴルフ
場の区域から場外の水域に流出する地点（以下「排水口」と いう.）において, 農薬濃度が高い状態になると予想される 時期の排出水について行われている. その際, ゴルフ場の構 造等によって排水口における調査が困難な場合には，場内の 調整池や排水路，またゴルフ場下流の河川等を含め，ゴルフ 場からの農薬の流出実態が適切に把握できると認められる地 点において調査が行われる.

（3）指針值について

指針中の別表に示された農薬（42成分）は, ゴルフ場で 使用されているものの中から全国的にみて主要なものを対象 に, 現在得られている知見等を基に人の健康の保護に関する 視点を考慮して排出水中の指針值が設定されている。さら に, 前述の水濁基準值が定められている農薬については, 当 該水濁基準值の 10 倍值がゴルフ場における暫定指針值とな る.

（4）改善措置について

排出水中の農薬濃度が指針值を超える場合には，ゴルフ場 下流に近接して水道水源等利水施設が存在する場合など, 調 査結果を周知すべき関係者に直ちに連絡し，当該施設等にお ける水質調査を行うとともに，ゴルフ場からの農薬の流出に 起因して利水目的の維持が困難とならないような措置が講じ られる。

（5）地域特性等への配慮

別表の指針值は，一般的条件の下で適用すべき暫定的なも のとして設定されたものであり, 都道府県において, ゴルフ 場の立地状況や下流の利水状況等地域の実情に応じ, 別表の 指針值にかわるより厳しい值による指導が行われている.

\section{3. 水濁法に係わる最近の話題と動向}

最新の知見や, 生じた諸問題に対応するため水濁法の改正 が行われてきたが，近年の改正の動きについて概略を示す。

1）平成 24 年 6 月 1 日施行

工場・事業場における有害物質の非意図的な漏えいや，床 面等からの地下浸透を防止し，回復が困難な地下水污染を防 止するため, 有害物質貯蔵施設等の設置者に対して施設構造

【立入り件数および排水基準違反の件数】

立入り件数: 39,490 件

違反件数: 4 件

違反業種: 畜産農業、生コンクリート製造業、金属製品製造業 - 機械器具製造業、弁当仕出屋·弁当製造業等

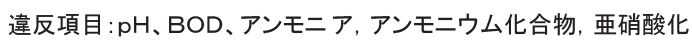
合物及び硝酸化合物、ジクロロメタン、SS等

…pHは違反事例が多く、要注意項目である。

図2. 平成 25 年度における立入り状況など ${ }^{11}$. 
の事前届出や構造基準の遵守義務化及び定期点検が義務付け られた。

2）平成 23 年 4 月 1 日施行

(1)排出水等の測定結果の改ざん等に対する罰則の創設

(2)事故時の措置の対象を追加

(1)については，ある事業所において，排出水の測定結果が 排水基準を超える測定結果であったが，長期間にわたり虚偽 の記録を行っていた事例が摘発されたため同様の事例が生じ ないよう改正が行われた。（2)については，今回の改正では污 水の流出事故が生じた場合に，事業者に対して応急措置の実 施及び地方自治体への届出を義務付ける「事故時の措置」の 範囲について, 以下の 3 点が変更された。

・従来の規制対象となっていなかった物質が指定物質として 追加された

・指定施設が新設された

- 従来の有害物質（表2）に加えて, 生活環境項目（表3） についても，事故により排水基準に適合しないおそれのあ る水が公共用水域に排出され，または地下に浸透したこと により，人の健康または生活環境に係る被害を生ずるおそ れがある場合には，事故時の措置の対象となった

このように, 諸問題や検出事例などから法改正が行われ, 規制対象施設や規制対象物質に対して追加や变更が行われる ため, 常に最新の情報を確認しておくことが必要となってい る.

\section{4. さらに詳しく知るには}

\section{参考資料}

・水濁法関係

環境省 HP: http://www.env.go.jp/water/mizu.html
・水質污濁に係る農薬登録保留基準について 環境省 HP: http://www.env.go.jp/water/dojo/noyaku/odaku_ kijun/index.html

・ゴルフ場暫定指導指針について

環境省 HP: http://www.env.go.jp/water/dojo/noyaku/golf_ course.html

- 環境白書

環境省 HP: http://www.env.go.jp/policy/hakusyo/

\section{引用資 料}

1）環境省水 大気環境局水環境課: 平成 25 年度水質污濁防止法等 の施行状況 : http://www.env.go.jp/water/impure/law_chosa /h25shiko.pdf

2）環境省: 水・土㙴・地盤・海洋環境の保全（一律排水基準） http://www.env.go.jp/water/impure/haisui.html

3）平成27年版環境・循環型社会・生物多様性白書 (PDF版): http://www.env.go.jp/policy/hakusyo/h27/pdf/full.pdf

略 歴
河原崎 海（かわらざき かい）
生年月日：1979年2月16日
最終学歴：神奈川大学大学院工学研究科応用化学専攻修士課
程修了
主な職歴：財団法人静岡県生活科学検査センター技術部, 株
式会社エコプロ・リサーチ分析センター
趣味：自転車, 釣り

